\title{
Universal Faith or Islamic Denomination: On the Struggle to Define Alevism
}

\author{
Ioannis N. Grigoriadis (D) and Pinar Akdeniz (D)
}

\section{Introduction}

The term "Alevi" is related to heterodox Islamic groups that have lived in Anatolia and its bordering regions since the introduction of Islam in the late eleventh century. It refers to a number of heterodox groups such as Kızılbaş, Tahtacı, Çepni and Ocakzade,

IOANNIS N. GRIGORIADIS (BA, University of Athens; MIA, Columbia University; $\mathrm{PhD}$, University of London) is Associate Professor and Jean Monnet Chair in the Department of Political Science and Public Administration at Bilkent University, Ankara, Turkey. He is the author of Democratic Transition and the Rise of Populist Majoritarianism: Constitutional Reform in Greece and Turkey (New York: Palgrave Macmillan, 2018). His other most recent publications are "For the People, Against the Elites: Left versus Right-Wing Populism in Greece and Turkey," The Journal of Middle East and North Africa 11, no. 1 (January-March 2020); (with Arzu Opçin-Kıdal) "Imagining Turan: Homeland and Its Political Implications in the Literary Work of Hüseyinzade Ali [Turan] and Mehmet Ziya [Gökalp],” Middle Eastern Studies 2020; (with Esra Dilek) "Securitizing Migration in the European Union: Greece and the Evros Fence," Journal of Balkan and Near Eastern Studies 21, no. 2 (June 2019). He has published in Middle East Journal, Mediterranean Politics, Democratization, Middle Eastern Politics, Journal of Middle East and North Africa, Southeast European and Black Sea Studies, Journal of Balkan and Near Eastern Studies, Constitutional Political Economy, Turkish Studies, Middle East Policy, and International Journal. Grigoriadis's primary research interests include religion and politics, democratization, nationalism, European and Turkish politics. This study was financially supported by the European Commission, Education, Audiovisual and Culture Executive Agency (Grant Code: EAC-A03-2016586489). PINAR AKDENIZ (BA, Bilkent University; MS, Uppsala University) is a PhD Candidate in the Department of Political Science and Public Administration at Bilkent University. Her primary research interests include religion, minorities, and Turkish politics. This study was financially supported by a 2019 American Research Institute in Turkey (ARIT) research grant, where she has been a research fellow. This article is in part based on the $\mathrm{PhD}$ research Ms. Akdeniz has conducted at the Department of Political Science and Public Administration, Bilkent University.

Journal of Church and State vol. 63 no. 1, pages 47-69; doi:10.1093/jcs/csaa028 Advance Access Publication May 1, 2020

(c) The Author(s) 2020. Published by Oxford University Press on behalf of the J. M. Dawson Institute of Church-State Studies. All rights reserved. For permissions, please e-mail: journals.permissions@oup.com 
and others that have traditionally practiced endogamy. ${ }^{1}$ The Alevis include Turkish, Zaza, Kurmanji, Pomak, Albanian, and Arabic speakers. ${ }^{2}$ Distinguishing themselves from Sunnis, they venerate Ali, son-in-law of the Prophet Muhammed, and are named after him. ${ }^{3}$ In addition to Ali, Alevis follow the Twelve Imams, as well as the teachings of Hacı Bektaş-i Veli, an Islamic mystic who lived in Anatolia in the thirteenth century. Alevis were often involved in uprisings against and faced persistent discrimination by the Ottoman state. Alevis underwent systematic persecution especially during the reign of Selim I; thousands of them revolted during the Celâli rebellions and were massacred because of their alleged loyalty to Shiite Iran and the Safavid dynasty and the threat they comprised for the Ottoman Nizam-1 Âlem (Global Order). Following the suppression of the revolts, Alevi communities never regained the trust of Ottoman authorities. ${ }^{4}$ The demographic size of the Alevi community has also raised controversy, due to the lack of census data and the prevalence of dissimulation practices among Alevis. Some studies estimated that the current Alevi population could amount to 15 to 20 percent of the Turkish population. ${ }^{5}$

Alevis hoped that the transition from the Ottoman Empire to a secular republic could rehabilitate them as equal citizens of republican Turkey. While most Alevis welcomed the advent of the

1. Anatolian Alevis often follow family lineage in the definition of their community, which led some scholars to define them as an ethnoreligious community. On the other hand, entering the Bektashi community was open to all disciples of dervish lodges affiliated to Hacı Bektaș Veli and his followers. The Bektashi sect became particularly popular among the Ottoman Janissaries and other Balkan converts to Islam. On this, see Karen Barkey, Empire of Difference: The Ottomans in Comparative Perspective (New York: Cambridge University Press, 2008), 16478.

2. Aykan Erdemir, "Tradition and Modernity: Alevis' Ambiguous Terms and Turkey's Ambivalent Subjects," Middle Eastern Studies 41, no. 6 (2005): 938-40.

3. Elisabeth Özdalga, "The Alevis-a "New" Religious Minority? Identity Politics and Turkey and Its Relation to the EU Integration Process," Religion, Politics, and Turkey's EU Accession, ed. Dietrich Jung and Catharina Raudvere (New York: Palgrave Macmillan, 2008), 177-79.

4. Barkey, Empire of Difference: The Ottomans in Comparative Perspective, 16163.

5. Ali Çarkoğlu and Nazlı Çağın Bilgili, "A Precarious Relationship: The Alevi Minority, the Turkish State and the EU," South European Society and Politics 16, no. 2 (2011): 353; Tahire Erman and Emrah Göker, "Alevi Politics in Contemporary Turkey," Middle Eastern Studies 36, no. 4 (2000): 99; Gisela Procházka-Eisl, "The Alevis," Oxford Research Encyclopedia of Religion, April 5 2016: 1-2, accessed February 26, 2020, https://oxfordre.com/religion/view/10.1093/acrefore/ 9780199340378.001.0001/acrefore-9780199340378-e-101; Martin van Bruinessen, "Kurds, Turks and the Alevi Revival in Turkey," Middle East Reports 200 (Summer 1996): 9-10. 
Republic of Turkey on October 29, 1923 and the abolition of the Caliphate on March 3, 1924, Alevism did not receive official recognition, and Alevis continued to face discrimination. Republican authorities refused to give them the status of a religious community and to recognize their houses of worship (cemevi). As in accordance with republican secularization policies, all religious orders and institutions (i.e. tekkes and zaviyes) were closed, and Alevi cemevis faced the same fate. In the aftermath of laws such as the Law on the Closure of Dervish Monasteries and Tombs, the Abolition of the Office of Keeper of Tombs and the Abolition and Prohibition of Certain Titles in 1925 and the establishment of Directorate of Religious Affairs in 1924, the principle of laicism (laiklik) was added to the constitution in 1937. The state did not only remove the religious authority but also pushed the religion back to a very narrow, private sphere. ${ }^{6}$ Meanwhile, the Directorate of Religious Affairs enjoyed a monopoly of the legitimate representation of Sunni Islam, ignoring Sunni religious orders and heterodox groups.

Turkey's sociopolitical transformation that started in the 1950s affected the Alevi community. ${ }^{7}$ As Alevis were mostly concentrated in the rural areas of Turkey, they have massively taken part in the urbanization wave, which transformed Turkish cities and the countryside. ${ }^{8}$ Urbanization also meant that Alevis, who used to live in relatively secluded rural environments and maintain distinct philosophy and religious practices separating them from the Sunnis, would come face to face with the Sunni majority in an unhospitable urban setting, which triggered tension and assimilation pressures. ${ }^{9}$ The "Alevi revival," which emerged in the 1960s and gained further momentum in the 1990s, was linked to urbanization and the transformation of Turkish society and resulted in the realization and reconstruction of Alevi identity, culture, and rituals. ${ }^{10}$ Many Alevi civil society organizations were established

6. Ioannis N. Grigoriadis, "Islam and Democratization in Turkey: Secularism and Trust in a Divided Society," Democratization 16, no. 6 (2009): 1196-97.

7. On the relations between Kemalism and Alevism, see Umut Azak, Islam and secularism in Turkey: Kemalism, Religion and the Nation State (London: IB Tauris, 2010), 139-73; Elizabeth Shakman Hurd, Beyond Religious Freedom: The New Global Politics of Religion (Princeton, NJ: Princeton University Press, 2017), 93-96. 8. Çarkoğlu and Bilgili, "A Precarious Relationship: The Alevi Minority, the Turkish State and the EU," 353.

9. David Shankland, The Alevis in Turkey: The Emergence of a Secular Islamic Tradition (London/New York: RoutledgeCurzon, 2003), 133-53.

10. Numerous Alevi associations were established during the 1960s, especially in rural areas. This proved crucial for the rediscovery of Alevis identity. Magazines such as Karahöyük (1964) and newspapers such as Ehl-i Beyt Yolu (1966) were also published in the 1960s. For more information, see Aykan Erdemir, 
not only in Turkey, but also in several other countries where Alevis migrated, including Germany. ${ }^{11}$ This revival had to overcome several legal and administrative obstacles that aimed to prevent political and social mobilization along the lines of religion or ethnicity. ${ }^{12}$ It also paved the way to increasing academic interest and the proliferation of Alevi organizations, associations, foundations, and federations. Nowadays, there are more than 300 Alevi associations and foundations in Turkey, with divergent understandings of what Alevism means and novel identities. ${ }^{13}$

\section{Aim of This Study}

The definition of Alevism has been a topic long contested in the relevant academic literature. Scholars such as Birdoğan, Melikoff, and Ocak ${ }^{14}$ argued that Alevism is not only linked to ancient faiths and traditions such as Shamanism, but also it has been heavily affected by cultures and traditions of Anatolia, hence creating a unique syncretistic belief intrinsic to the region and opposed to orthodox Islam. ${ }^{15}$ Nevertheless, this definition attempts to pose an important self-reflective point that Alevis use as a tool to both stress their own identity, as well as to avoid the pressure of Sunni Islam. Dressler argued that Alevis insist on their difference from Sunni Islam by marginalizing themselves within Ottoman and Turkish societies and by letting their ritual practices be influenced by Twelver Shiite mythology, Islamic mysticism, and other non-Islamic traditions. ${ }^{16}$ Objecting to the rise of political

"Cumhuriyet Dönemi Türkiye'sinde Alevi-Bektaşi Örgütlenmeleri,” in Geçmişten Günümüze Alevi-Bektaşi Kültürü, ed. Ahmet Yaşar Ocak (Ankara: T.C. Kültür Bakanlığı Yayınları, 2009), 168-70; Elise Massicard, "Alevism in the 1960s: Social Change and Mobilisation," Alevis and Alevism: Transformed Identities, ed. Hege Irene Markussen (Istanbul: Isis Press, 2005), 121-24.

11. Martin Sökefeld, Struggling for Recognition: The Alevi Movement in Germany and in Transnational Space (New York, Oxford: Berghahn Books, 2008), 64-92 https://books.google.com.tr/books?id=_sEtYfs2S4MC.

12. Elise Massicard, "Claiming Difference in an Unitarist Frame: The Case of Alevism," in Turkey Beyond Nationalism: Towards Post-Nationalist Identities, ed. Hans-Lukas Kieser (London/New York: I.B. Tauris, 2006), 75-78.

13. Özdalga, "The Alevis-a "New" Religious Minority? Identity Politics and Turkey and Its Relation to the EU Integration Process," 187-89.

14. Nejat Birdoğan, Alevilik: Anadolu'nun Gizli Kültürü [Alevism: The Secret Culture of Anatolia] (İstanbul: Kaynak Yayınları, 2013); Irene Melikoff, Uyur Idik Uyardılar [They warned us while we were sleeping] (Istanbul: Demos Yayınları, 2015); Ahmet Yaşar Ocak, Alevi ve Bektaşi İnançlarının İslam Öncesi Temelleri [The Pre-Islamic foundations of the Alevi-Bektashi faith] (İstanbul: İletişim, 2015).

15. On the definition of Alevism, see also Hurd, Beyond Religious Freedom: The New Global Politics of Religion, 89-93.

16. Markus Dressler, "Religio-Secular Metamorphoses: The Re-Making of Turkish Alevism," Journal of the American Academy of Religion 76, no. 2 (2008): 281. 
Islam and the Turkish-Islamic Synthesis (Türk-İslam Sentezi) in the 1980s, Alevis started to differentiate themselves from Sunni Islam not only by dating Alevism before the birth of Islam, but also by putting emphasis on their Turkish nationalist credentials through an emphasis on the Central Asian elements of their faith. ${ }^{17}$

This study aims to manifest that this confusion and identification dilemma remains dominant among Alevi civil society organizations. While Alevis are understood as a minority group in Turkey with distinct features from Sunni Islam, their definition of Alevism varies considerably. This article focuses on the internal boundary contestations among Alevi civil society organizations in Turkey. In particular, it discusses how Alevism is defined by leading Alevi civil society groups. Lacking a unified structure and a holy text guiding the faith, Alevi organizations such as Pir Sultan Abdal Culture Associations (Pir Sultan Abdal Kültür Dernekleri (PSAKD)), Hacı Bektaş Veli Anatolian Culture Foundation (Hacl Bektaş Veli Anadolu Kültür Vakfı (HBVAKV)), and Alevi Culture Associations (Alevi Kültür Dernekleri (AKD)) define Alevism as "a path," "a philosophy," or something that reflects universal values. On the other hand, Cem Foundation (Cem Vakfi) and World Ahl alBayt Foundation (Dünya Ehl-i Beyt Vakfl (DEBV)) define Alevism as a part of Islam. This study argues that intragroup boundaries and boundary contestations become apparent when some groups contract the boundaries of Alevism by excluding Islam, while other groups expand and blur the boundaries of Alevism in an effort to associate Alevism with Sunni Islam and avoid any confrontations with the Turkish state. The definition of Alevism as a path or a way of life, which is addressed by PSAKD, HBVAKV, and AKD, is introduced first, and how this definition both contracts and universalizes the boundaries of Alevism is discussed. Second, the definition of Alevism lined with Islam which is represented by Cem Vakfi and DEBV is presented, and the ways these foundations expand and blur the boundaries of Alevism by defining Alevism as part of Islam is discussed.

This study utilizes the boundary-making approach to understand Alevism, specifically how boundaries contract and expand in order to understand different definitions of Alevism made by Alevi civil society organizations. This approach focuses on how boundaries are drawn through limiting, reproducing, and constructing different national or ethnic categories and can differ from one association to another, as their own definitions of

17. Markus Dressler, "Irene Melikoff's Legacy: Some Remarks on Methodology," Türk Kültürü ve Hacı Bektaş Veli Araştırma Dergisi 52 (2009): 19-20. 
Alevism and Islam vary considerably. ${ }^{18}$ Wimmer argued that the boundary-making approach offers reciprocal and dynamic interaction of intergroups that helps us understand how boundarymaking processes occur on ethnic, religious, or national levels. ${ }^{19}$ In his view:

Researchers would no longer study 'the culture' of ethnic group A or B, but rather how the ethnic boundary between A and B was inscribed onto a landscape of continuous cultural transitions. Ethnicity was no longer synonymous with objectively defined cultures, but rather referred to the subjective ways in which actors marked group boundaries by pointing to specific diacritics that distinguished them from ethnic others. ${ }^{20}$

Therefore, in contrast to former studies of boundary-making that ignored the boundary's content, recent studies have emphasized the symbolic boundaries and their content (i.e., "cultural stuff") of ethnic and national categories. ${ }^{21}$ Thus, whenever there is a boundary set by one side, it is always in relation to or through engaging with the others. ${ }^{22}$ Moreover, whenever selfidentification of a group changes, so does the boundary. The Alevi case is a significant example to examine how symbolic boundaries are constructed. Following the Alevi revival, many organizations were established, and while some adopted a Sunni Islam-friendly approach toward their perspective on Alevism, others embraced a more syncretic attitude. As a result, even though Alevis were regarded as a unified entity from outside, they have in fact remained divided based on their perspective on Alevism. By embracing diverse standpoints, Alevi organizations' leaders have continued redrawing symbolic boundaries of Alevism in Turkey.

18. The same approach could be applied regarding Sunni Islam, as different Sunni groups have suggested different definitions of Islam. Yet such an endeavor lies beyond the scope of this study.

19. Andreas Wimmer, Ethnic Boundary Making: Institutions, Power, Networks (New York: Oxford University Press, 2013). The ethno-religious character of the Alevi community renders it a particularly suitable case for Wimmer's model, which was developed with reference to ethnic groups.

20. Wimmer, Ethnic Boundary Making: Institutions, Power, Networks, 22-23.

21. Daniele Conversi, "Nationalism, Boundaries, Violence," Millenium: Journal of International Studies 28, no. 3 (1999): 553-54; Richard Jenkins, Rethinking Ethnicity (London: Sage, 2008), 111-27; Joane Nagel, "Constructing Ethnicity: Creating and Recreating Ethnic Identity and Culture, " Social Problems 41, no. 1 (1994): 161-67, http://www.jstor.org/stable/3096847; Wimmer, Ethnic Boundary Making: Institutions, Power, Networks, 22-23.

22. For a comparative study of Greek and Turkish nation-building, also see Ioannis N. Grigoriadis, "Redefining the Nation: Shifting Boundaries of the 'Other' in Greece and Turkey,” Middle Eastern Studies 47, no. 1 (2011): 167-68. 


\section{Who Are the Alevis?}

Bilici introduced four distinct approaches to Alevism that are popular among different groups. ${ }^{23}$ The first describes Alevism as an ideology featuring diverse religious, cultural, and even Marxist elements, such as class struggle. This branch rose to prominence after the 1980 coup d'état and more importantly after the collapse of the Soviet Union. It followed Pir Sultan Abdal and his teachings. This was the time that the PSAKD emerged and published their homonymous monthly journal. The group identified Alevism as a way of life influenced by different religions rather than a separate religion in itself. In the words of Hikmet Ylldırım, head of PSAKD:

The way of life of the Alevi in Turkey resembles the way of life in no other Islamic country. It resembles neither the Shi'a of Arabia and Iran, nor of Libya and Egypt. Anatolian Alevism displays a quite individual structure, having adopted an Alevite form after coming under the influence of all of the various cultures that had previously existed in the region. Of those may be mentioned Zoroastrianism, Christianity and Islam. Nevertheless, it has fused with none of these .... Alevism is situated neither totally within nor totally outside the religion of Islam. ${ }^{24}$

The second approach focuses on Islamic mysticism and heterodoxy, which have no clear boundaries. ${ }^{25}$ They are mostly united under Hacı Bektaş Veli Associations and lodges, which emphasize the individuality of love of God. For them, love of God is the essence of everything. They believe that no religion is superior to another, and the love of God one bears is more important than one's piety to the other.

The third approach evolves around the combination of Sunni Islam and Alevism through the teachings of Imam Ja'far al-Sadıq. It is argued that there are fundamental differences in worship, belief, and interpretation of the religious texts such as the hadith and Quran. ${ }^{26}$ Even though these Alevis accept the Quran as one of their religious texts, they still believe that the original text distorted in some way that some parts were omitted and the current version is not the original one. Hence, they focus on Islamic jurisprudence (figh) and interpret it as Alevi figh. This means that all

23. Faruk Bilici, "The Function of Alevi-Bektashi Theology in Modern Turkey," in Alevi Identity: Cultural, Religious and Social Perspectives, ed. Tord Olsson, Elisabeth Özdalga, and Catharina Raudvere (Istanbul: Swedish Research Institute in İstanbul, 1998), 51-54.

24. Ibid, 52.

25. Ibid, 53.

26. Ibid, 54 . 
decisions taken either individually or as a community have to be based on one's free will. Hence, human life is engaged in the real world unlike Sharia.

The fourth approach follows the Twelve Imams and Iranian Shi'ism. These Alevis have their own imams and separate mosques from Sunnis. They also distinguish between Bektashis and Alevis. They argue that Alevis are included in Twelver Shi'a, while the Bektashi order is merely an institution established by Ottomans to avoid the spread of the Twelve Imam doctrine and keep Anatolia under their control. They believe that the genuine Twelve Imam doctrine never reached Anatolia, because Alevis only gained knowledge of their Muslimness through Sunni understandings, first in the Ottoman and then in the republican era. In addition, this line of thought believes that congregation halls, cemevis, are not a venue for worshipping but for entertainment, whereas mosques are the real place to practice namaz. Examining all these different approaches of Alevism helps clarify that even while Alevis are normally addressed as a single homogeneous community, they rather resemble a mosaic in their diversity.

\section{Modes and Means of Boundary-Making}

During boundary-making, actors are encouraged by material interests, such as economic or political power, and ideational interests, such as legitimacy and recognition. In an effort to pursue these goals, they apply various strategies. Among these strategies, Wimmer identified five main strategies, namely expansion, contraction, transvaluation, positional move, and blurring. ${ }^{27} \mathrm{Ex}-$ pansion refers to shifting the existing boundary in order to contain and incorporate other groups. Contraction, on the other hand, refers to the diminishing or shrinking the existing boundary by excluding certain groups or categories. Both of these boundary-making strategies could be visible on both symbolic and social levels. As boundary makers, elites and leaders aim to adjust symbolic boundaries or redefine these boundaries in order to define insiders and outsiders. Another boundary-making strategy is called transvaluation where the hierarchical orders of the boundaries are challenged. Transvaluation has two varieties: normative inversion and equalization. Normative inversion refers to the challenge to the boundaries by the excluded group arguing that they have moral or cultural superiority to the dominant

27. Wimmer, Ethnic Boundary Making: Institutions, Power, Networks, 50-56. This categorical tool could be also applied to other communities such as Isma'ili, Druze, and other branches of the Islamic faith. 
group. On the other hand, equalization aims to bring moral and political equality between excluded and dominant group. Positional move refers to one's individual crossing of a boundary or collective repositioning of the boundary, in case transvaluation is not happening. Finally, boundary-blurring aims to reduce the significance of boundaries along ethnic lines by emphasizing shared values, ideas, symbols, and culture. By eliminating cleavages and ideas that cause boundaries, boundary-blurring aims to reduce the salience or significance of categories in an effort to create a shared value and harmony. ${ }^{28}$ Boundary contestations are another significant feature of boundary-making processes since they require involvement of different actors as well as diverse interests, power, and authority. ${ }^{29}$ Through an analysis of how Alevi civil society organizations define Alevism, this study discusses how these strategies are applied by Alevi civil society organizations. The findings of this study suggest that some Alevi organizations adopt an Islam-friendly approach where they can combine Alevism with Sunni Islam by referencing Islamic ideas and principles and can expand and blur the boundaries of Alevism. Other organizations redefine the boundaries of Alevism and challenge its hierarchy to Sunni Islam by defining it as a faith that has been affected by many religions and rituals extant before the birth of Islam; therefore, it is a universal faith older than Sunni Islam.

\section{Alevism as a Universal Faith}

This definition of Alevism as a universal faith is primarily addressed by Pir Sultan Abdal Culture Associations (PSAKD), Hacl Bektaş Veli Anatolian Culture Foundation (HBVAKV), and Alevi Culture Associations (AKD). Refusing to recognize Alevism as part of Islam, these Alevi organizations believe that Alevism has been influenced by Christianity, Judaism, Zoroastrianism, and other Central Asian and Shamanic beliefs. In this section, two strategies of boundary-making, expansion, and transvaluation are examined. While some Alevi civil society organizations such as PSAKD, AKD, and HBVAKV believe that Alevism is an old belief combining and encompassing other beliefs, they expand the boundaries of Alevism. On the other hand, they contract the boundaries of Alevism stating that Alevism existed before Islam and it is something intrinsic to Anatolian culture and therefore, cannot be associated with the essence of Islam or Islam itself. As

28. Wimmer, Ethnic Boundary Making: Institutions, Power, Networks, 57-61.

29. Zeki Sarıil, Ethnic Boundaries in Turkish Politics: The Secular Kurdish Movement and Islam (New York: New York University Press, 2018), 38-39. 
Ali Balkız, an Alevi intellectual, former head of Alevi associations, and editor of the Pir Sultan Abdal Kültür ve Sanat Dergisi defined:

Alevism is more of a way of life than a system of beliefs. It is the way of interpreting the world, nature, society and the individual. It is the set of rules that regulates the relationship between society and the individuals. It is a system that focuses on this world instead of afterlife and emphasises reality instead of myths. It prioritises human beings and puts them in the centre of its philosophy. But most importantly, it focuses on today's problems. Alevism is traditional, but at the same time it is not dogmatic; it is always contemporary and up-to-date .... It is the way of life of Anatolian folk. As much as it was affected by Islam, it still kept its Shamanic roots and added a little bit of Buddhism and Christianity to it. $^{30}$

Among the Alevi civil society organizations, perhaps one of the most influential is PSAKD, which derives its name from the famous Alevi minstrel Pir Sultan Abdal. This association believes that Alevism is a universal belief and has existed since the beginning of humanity. Instead of emphasizing Alevism as a religion and God's will above all, they believe that it is a synthesis of all beliefs and cultures that have existed all over the world. So, it is neither a religion nor a dogmatic belief, but it is a universal and eternal faith. As Turgay Özkan, the general secretary of PSAKD, said:

Alevism is a path that leads people to become better individuals. While doing so, Alevism do not reject whatever belief comes before and after and take what is good about these beliefs and internalize them. Alevism is a way without any written rules yet internalizes these rules, and Alevis conduct them in their everyday lives in a virtual city called 'The City of Consent' (Rıza Şehri). We consider following these rules as our prayer. The language of Alevism can be found in the Torah, the Quran, the Book of Psalms, and Shamanism, as well as the rules followed by the Inca tribes .... The sources of Alevism could be traced in the beginning of the humanity. ${ }^{31}$

Here, in addition to emphasizing how Alevism blends all the faiths and religions in its body, Özkan also stressed Alevism's antiquity. This argument is quite striking in the sense that in most of the cases it is observed that while defining Alevism, most of the Alevi organizations argue that it had been affected by many faiths and religions as well as Turkic nomadic traditions, but they do not claim that Alevism emerged with the beginning of

30. Ali Balkız, "Diyanet'in Kapısına Kul Olmak" [Being a servant at Diyanet's door], Pis Sultan Abdal Kültür Sanat Dergisi 1, no. 1 (1992): 7.

31. Turgay Özkan, “Interview, ” interview by Pınar Akdeniz, April 19, 2019. 
humanity. Thus, instead of situating Alevism inside Islam or as a sect under any religion, which is to be discussed in the following section of this article, this perspective argues that Alevism has a tradition that comes a long way, was affected by many faiths during the course of the history, but is not to be defined against them, as it predates them.

Other emphasized components of Alevism include reaching wisdom through individual improvement, as well as equality. Onur Kaya, a member of the executive board of PSAKD, was critical on religion and its structure in general. He explained how the structure of worship in Alevism differs from other religions and how God is understood. In doing so, he also defined what an ideal, that is, wise, person means for Alevis:

Alevism means humanity. It is a very broad definition, but that is what makes us different from others. We have a structure that does not feel the need to be defined. A person says there is one God above and his teachings and holy scriptures, and there is the Prophet who delivers his commands and after him there are the believers who follow him. We reject all this. We believe that humans try to reach God by shaping his life through different ways of worship and they reach God. This is the effort to become a wise person (insan-ı kâmil). In the end, he or she becomes one with the God. We call this process the 'Unity of Existence' (An-al Haqq). At that point, that person reaches God. ${ }^{32}$

Another argument along this line of thinking posits that instead of identifying Ali as a legendary character who is strong and capable of everything, Ali is perceived as a person who defends the rights of the people and strives for equality. Since Ali is one of the founding blocs of Alevism, it is crucial to discuss about how Ali is perceived and portrayed in the eyes of Alevis. One of the most significant examples of this account is the book named "Alevism without Ali" (Ali'siz Alevilik) published by Faik Bulut, an Alevi academic who often writes for PSAKD's monthly journal Pir Sultan Abdal Kültür ve Sanat Dergisi. Bulut's book received a lot of attention and diverse reviews by different Alevi groups. ${ }^{33}$ He explored pre-Islamic evidence of Alevism and argued that Alevism is not part of Islam. He added that many Alevis, as well as the Turkish, have attempted to subjugate Alevism to Sunni Islam by using the Turkish-Islamic Synthesis. Arguably one of the most important arguments Bulut made referred to the portrayal of Ali in Alevism, striking a lot of attention by Alevis and Sunnis alike. According to Bulut, Ali is portrayed nowadays in two ways. First, there is the

32. Onur Kaya, "Interview," interview by Pınar Akdeniz, April 19, 2019.

33. Faik Bulut, Ali'siz Alevilik [Alevism without Ali] (İstanbul: Berfin Yayınları, 2007). 
prophet Ali and second, there is the legendary Ali who is elevated in the eyes of the believers. His arguments caused a lot of reactions by many Alevis, even to the point of some questioning his own Alevism. In his own words:

For me, there are two Alis. First one is the real Ali, who protects Sharia and Islam, the one who advised Abu Bakr, Omar and Osman, the one that blood drips from his sword and guides the armies. The second Ali is imaginary and legendary Ali who is a hero. He never lived. He is a folk hero just like Zağaloğlu, Rüstem, Köroğlu and Dadaloğlu. He is very strong to the point where he can pull out a door with a single swing. He is married to Fatima, and he is the beloved father of Hasan and Hussein. He is the lion of God and is the superior of the Prophet who made him kiss his ring. He is a Mahdi, who will return to this world and bring justice and equality. He supports the poor, strives for equality and is up to a point (sic) a leftist. He is quite tolerant about religious matters and, in fact, he does not even perform the namaz and the oruç (Ramadan fasting). He is the enemy of Abu Bakr, Osman, Omar and Muawiya and calls them 'tyrants'. In fact, Ali has black eyes and black hair and is handsome like Prince Charming. It is not important if he has Turkish, Persian or Kurdish background, but in the minds of Turkish Alevis, he is the true Turk'. ${ }^{34}$

On the other side, Melikoff, one of the most prominent scholars on Alevis, observed that Ali is perceived almost as God by some Alevis. Bulut quoted an interview of Melikoff where she answered the question on how she observed a difference between the two Alis: "I see a huge difference. You know there is a saying: I recognize no God but Ali (Men Ali'den başka Tanrl bilmezem)." And then she added that one of the Alevis she met told her how Ali is in fact deified: "One day Shah [Ali] was carried away and revealed the secret. He said to Omar that he is the one who roars from the sky. All sky was struck by the lightning, and he roared to seven skies. He is the one that everlasting and divine light of the God." And then Melikoff adds: "This is not Ali that actually lived in history. So, Ali could become a Tengri and many other things in this hymn."35

On another level, Alevis draw a different portrait of Ali where they chat, complain, and make jokes to Ali as they speak. So, Ali is a friend with whom they can chat about the day, but he is also the one that takes revenge on oppressors and tyrants. But most importantly, even though tales about Ali are mythical and legendary, he is the symbol of equality and justice. In fact, by referring to the tale of the "Gathering of the Forty" (Kırklar Cemi), Alevis argue

34. Faik Bulut, "Ali'nin Tanrısallaştırılması" [Divinification of Ali], Pir Sultan Abdal Kültür Sanat Dergisi 7, no. 29 (1998): 36.

35. Ibid, 36. 
that Ali accepted Mohammad to the gathering only after he agreed to enter the cem as "one of the souls (can)." This way of acceptance shows that Alevis care for equality and perceive cem as a "unity of equality." Hence, many Alevis refer to him as one of them and believe that he will bring justice one day. In fact, Ylldırım quotes Ali Kızıltuğ, one of the contemporary Alevi minstrels, who wrote this hymn to show that Alevis would be disappointed and angry, if their beloved Ali would not be able to bring justice:

Seni sevenlerin yaralı dertli

Şu elin zalımı bizden kıymetli

Keramet sahibiydin güçlü kuvvetli

Yoksa bir kul idin öldün mü Ali?

Zalimin zulmü bizi yakarsa Bizi ağlatıp karşımızdan bakarsa

Ahirette elim boşa çıkarsa
The ones who love you are in pain and sorrow

That foreign oppressor is more valuable than us

You delivered miracles, had power and might

Or were you a slave, did you die, Ali?

If we are oppressed by the tyrants

By the ones that makes us cry

If my hand proves empty in afterlife

Tutar o Zülfikar'ı kırarım, Ali. I will grab and break your Zülfikar [sword], Ali. ${ }^{36}$

Even though Alevis put forth the humane and ordinary side of Ali, many of them still do believe that legends about Alevism bring them together. In fact, Sercan Aydoğan from PSAKD also agreed on this account, stating that these legends are part of Alevis' life and what connects them:

When Alevis come together in villages, they often talk about cönks, the compilations of legends that Anatolian poets once wrote. In that way, people are carried away and become more loyal to their faith. Since Alevis do not come together as often as they can, compared to traditional village gatherings and cems, they talk about legends. Legends are part of our lives. Of course, we know that Ali's sword will not extend as much as forty yards, while he is fighting, but the important thing is that legends are one of the key elements to keep our faith alive. ${ }^{37}$

36. Ali Yıldırım, “Tutar Zülfikar'ını Kırarım Ali” [I will grab and break your Zülfikar [sword], Ali], Pir Sultan Abdal Kültür Sanat Dergisi 7, no. 29 (1998): 57.

37. Sercan Aydoğan, "Interview, " interview by Pınar Akdeniz, April 20, 2019. 
Hence, these associations and foundations perceive Ali not with his deified, legendary persona, but rather as a person that pursues equality, fights back against oppression, and has lived and died back in the day, but will return to this world to bring justice. By referring to Ali, they especially put forward the concept of humanity and the humane side of Ali.

A similar argument claiming the antiquity of Alevism and its amalgamation with other religions sheds light on its relationship with Islam. In that view, Alevism is a syncretistic belief that predates Islam and fuses Christian, Judaic, Shamanistic, Zoroastrian, and other elements in its body. But most importantly, besides arguing for multiple influences upon Alevism, these Alevi organizations situate its history. Hence, they engage in transvaluation. As stated in Wimmer's theory, the boundaries of Alevism are changed and repositioned in relation to Islam, claiming that Alevi faith existed way before Islam and therefore comes before Islam, making Alevism an ancient and old belief, which later absorbed Islamic elements to its body. ${ }^{38}$ Murtaza Demir, one of the founding members and former head of PSAKD argues that even though Alevism has been affected by Islam, it is not entirely representing Islam. As Demir wrote to PSAKD monthly journal:

We do not believe that Alevism is a genuine part of Islam. On the contrary, we believe that Alevism is a whole belief which has been affected by Islam throughout the years of its development and thus, carry its footprint. At the same time, we also believe that Alevism is a faith intrinsic to Anatolian culture and philosophy. ${ }^{39}$

Hakan Yavuz, another scholar who wrote for the PSAKD journal also did not deny the fact that Alevism has been affected by Islam and has been amalgamated with many religions throughout history. In his view:

Alevis has a syncretistic belief system. Even though the main source of Alevism is Anatolian mysticism, one could still find traces of Shamanism, Shiism, and Christianity. Turkic tribes and local Anatolian groups, which accepted Islam in various phases and ways, perceived and interpreted Islam in different fashions. From the two main interpretations, one came to life as Alevism and the other as Sunni Islam. ${ }^{40}$

38. Wimmer, Ethnic Boundary Making: Institutions, Power, Networks, 57-58. 39. Mustafa Demir, "1992 Yılının Derneğimiz Açısından Kısa Özeti ve Bir Yanıt” [A short summary of the year of 1992 about our association and a ahort answer], Pir Sultan Abdal Kültür Sanat Dergisi 2, no. 5 (1993): 3.

40. Hakan Yavuz, "Anadolu Tasavvufunun Yetimleri Aleviler" [Alevis: the orphans of the Anatolian mysticism], Pir Sultan Abdal Kültür Sanat Dergisi 9, no. 40 (2000): 6. 
Here, Yavuz also claimed that Alevism is a syncretistic belief and stressed that it was integrated with beliefs such as Shamanism and Christianity. But he also asserted that Turkic tribes started to accept Islam much later, and this is how these differences between Alevism and Sunnism became visible. Hence, Yavuz specifically situated Alevism before Islam. Alevism is not Islam itself, or the essence of Islam, but in its long history, it has somehow incorporated Islam together with other religions. This line of thought asserts that Alevism is not solely based on Islam, but as the faith evolved, it amalgamated Islam into its body. Nevertheless, one still makes a distinction between Alevism and Islam. As Ali Balkız, former head of PSAKD also concurred, "Islam has its own set of values. But one should not forget that Alevism has its own values as well." 41

The concept of Anatolian Alevism (Anadolu Aleviliği) is a notion that Alevism has strong, indelible connections with Anatolian culture, which nourished Alevism. This perspective is especially maintained by PSAKD, HBVAKV, and AKD. They do not only focus on how Anatolian culture influenced Alevism, but also how Alevism differs from Islam arguing that Anatolian Alevism is a contemporary and open-minded faith compared to Sunni Islam. This perspective is especially visible in the writings of Alevi intellectuals, as they scrutinize the significance of Alevism through its comparison with Sunni Islam. As Lütfi Kaleli, a prominent Alevi intellectual, stressed, Anatolian Alevism is only connected to Islam with its attachments to Ali and Ahl al-Bayt, but it could never be associated with Umayyad Islam that was shaped by Muawiya. He then added:

In Anatolian Alevism, Ali, as opposed to his Islamic portrayal, is the symbol of honesty and bravery, and he is always the enemy of the unjust and tyrant. That is how Anatolian Alevis love Ali .... They do not consider namaz, fast and hajj acceptable. As Hacı Bektaş Veli once said, Anatolian Alevis believe that human beings are the best books to read and agree with his saying: 'Whatever you are looking for, always look inside yourself; you will not find it in Jerusalem, Mecca or Hajj.' Even though Anatolian Alevism somehow ended up inside Islam, Islam is not the essence of it. Anatolia's rich culture is the one that nourishes Alevism. Anatolian Alevis are not fatalist, but they follow reason and distinguish right from wrong. 42

41. Ali Balkız, "Danışma Kurulu Açılış Konuşması" [Opening speech of the advisory council], Pir Sultan Abdal Kültür Sanat Dergisi 9, no. 38 (2000): 11.

42. Lütfi Kaleli, "Aleviliği Kültür Saymayan Kültürsüzdür” [Whoever says Alevism is not a culture is without any culture], Pir Sultan Abdal Kültür Sanat Dergisi 2, no. 5 (1993): 20. 
Similarly, Nedim Şahhüseyinoğlu elaborated on this issue stating that the only common point of Alevism with Islam is that Alevis accept Muhammad as the Prophet and Ali as his Caliph, but they do not follow the terms of Islam. ${ }^{43} \mathrm{He}$ also made a clear distinction stressing as most of the Alevis proudly argue: "Anatolian Alevism is a political movement against Arab culture. It is neither narrow-minded nor bigoted, but it is open-minded and has love for the people in its core. It aims at progress and is always modern." ${ }^{4}$ By stressing the difference of Anatolian Alevism, both authors argue that what they address as Anatolian Alevism is not only a belief blended with Anatolian culture, traditions, and poets. It is also something unique that distinguishes itself from Islam: It strives against formalism of some strict rules and focuses on reason and how it shapes their way of life. By emphasizing Anatolian Alevism, which infuses various religions and faiths together with Anatolian culture, these Alevi civil society organizations distinguish themselves from other Alevi organizations that champion an Alevi-Islam convergence by arguing that Alevism is the essence of Islam. PSAKD, AKD, and HBVAKV contract the boundary of Alevism and maintain that Alevism existed long before Islam and, therefore, is not the product of Islam. Tuncer Bass, the head of HBVAKV, defined Alevism as a way that is based on the principle of the "unity of existence" (wahdat alwujud) introduced by Sufi metaphysics, where God is omnipresent, and therefore his creations everywhere are part of him. So, God exists inside every being, since they are his creations. In his view:

Alevism met Islam a thousand and five hundred years ago. From that angle, it is not outside of Islam. Alevism is an ancient belief and includes Islam, not the other way around. It showed itself with Islam, but it is not heterodox to Islam. If Islam is an orthodox belief, then Alevism is not heterodox because it also includes Islam. ${ }^{45}$

Even though this explanation seems confusing at first, the head of the Foundation clearly claimed that Alevism is an ancient belief, existing long before Islam. Nevertheless, he stressed that

43. The notion of caliphate was formulated in Medina following the death of $\mathrm{Mu}-$ hammad in 632. Internal tensions were exacerbated following the death of the Prophet's grandson Hussein as well as his followers by Yazid, the Umayyad caliph during the Battle of Karbala in 680. For further reading on the notion of caliphate and how it evolved over time, see Cemil Aydin, The idea of the Muslim world (Cambridge, MA: Harvard University Press, 2017), 19-25.

44. Nedim Şahhüseyinoğlu, "Anadolu Aleviliği” [Anatolian Alevism], Pir Sultan Abdal Kültür Sanat Dergisi 2, no. 10 (1993): 31.

45. Tuncer Baş, “Interview,” interview by Pınar Akdeniz, April 22, 2019. 
over the course of time, Alevism met with and included Islam, its values and traditions. Baş did not state that Alevism is Islam, but he argued that Alevism has been influenced by Islam. That is why he rejected the idea that Alevism is a heterodox belief and should be marginalized. The definitions that Baș, Özkan, and other scholars and activists suggest are rather interesting, given that they do not only fit to the scholarly argument that places Alevism as a syncretistic belief affected by many religions, but also claim its antiquity. They all argue that Alevism is an ancient belief that preceded Islam and, in fact, as Özkan said, has existed from the very beginning of the humanity.

Another view defines Alevism as intrinsic to Anatolian folk and culture. In what is often referred to as Anatolian Alevism, it is argued that the way current Alevism came into being blended various faiths with Anatolian culture, in particular poets and minstrels. Kaya argued that Alevism has been influenced by many events that took place in Anatolia In his words:

Anatolian Alevism was influenced by important poets such as Nesimî and Mansur Al-Hallaj as well as Sheikh Bedreddin, even though he was Sunni. The path that Anatolian Alevism takes is twofold: first, it takes us back to the ancient civilisations of Anatolia and second, it includes Islam and the beliefs that they emerged before and after .... Alevism has borrowed a lot from the Quran, the Bible, and the Torah. Our faith dates back to the time Noah lived; we borrowed traditions from Zoroastrianism and Shamanism. That is why it is a blend of all faiths. Alevism has been affected by all of them, and we try to borrow the best parts of these faiths. ${ }^{46}$

An additional difference between Anatolian Alevism and Sunni Islam refers to their treatment of ethnicity or race. According to this argument, Alevism is a belief that does not discriminate but treats all humans as equals due to their intrinsic value as human beings. While arguing this, however, they make a clear distinction between Alevism's equal treatment of all national, ethnic, and racial groups and Sunni Islam's stance, which is viewed as restrictive and intrinsic to Arab culture. This perspective was openly stated in an editorial published in PSAKD's journal:

Anatolian Alevism does not belong to a race or a nation. It is a culture specific to Anatolia, and one cannot claim that a faith belongs to a particular nation. In Anatolia there are Turkish Alevis, as much as Kurdish Alevis and Arab Alevis. On the other hand, in Islam God's power is absolute, and his commands cannot be changed or open to discussion. Women are often ignored or repressed. Music is forbidden during rituals. Men can

46. Kaya, interview. 
marry more than one woman .... But most importantly, Islam perceives Arabs as the only superior nation. Moreover, jihad is one of the most important components in Islam. On the other hand, Anatolian Alevism blends God, human beings and nature all in one, where men and women are equal, and music and semah are the sine qua non of our rituals. Among all others, instead of accepting a single nation as superior, Alevism accepts all seventy-two nations as equal (72 millete aynı gözle bakar) and considers them brothers and sisters. ${ }^{47}$

The author made a clear distinction between Alevism and Islam where Alevism is an all-encompassing faith, valuing equality of men and women, and, can be, therefore, considered as modern. In contrast to that, Sunni Islam is understood as "essentially Arabic" and "backward".

\section{Alevism as an Islamic Denomination}

The second leading definition of Alevism reconciles it with Sunni Islam and is represented by Cem Vakfı and DEBV. These Alevi organizations tend to expand the boundaries of Alevism, in an effort to blend Alevism within Islam, arguing that Alevism is in fact, the essence of Islam.

Cem Vakfl was established on March 27, 1995. Its name ingeniously emphasizes both its attachment to Alevism by using the word cem (i.e., cem ritual as well as cemevi, congregation hall in which cems takes place), while also stressing its commitment to republican Turkish values, since its full name is Republican Education and Culture Center Foundation (Cumhuriyetçi Ĕgitim ve Kültür Merkezi Vakfi). Cem Vakfi stands for an approach that combines Alevism with Islam, which they often refer it as AleviIslam, and their mission is to champion an Alevi-Islamic Synthesis (Alevi-İslam Sentezi). On the third anniversary of the establishment of Cem Vakfl, İzzettin Doğan, honorary president of the Foundation, wrote:

We stated to state officials and everyone before we established this Foundation that the Alevi-Islamic faith reflects Islamic Sufism and it encapsulates the nomadic tribal Turkic and Anatolian folk understanding of Islam. We tried to show that no matter what nation people belong to or what language they speak, the essence of Quran is love and is the strongest tie between human beings and the God. ${ }^{48}$

47. Editorial, "Yeni Dünya Düzeninin Alevilik Tarifi: Gerçek Türk-İslam Sentezi Alevilikmiş" [The description of Alevism of the New World Order: Alevism is the real Turkish-Islam synthesis], Pir Sultan Abdal Kültür Sanat Dergisi 5, no. 18 (1996): 29.

48. İzzettin Doğan, “Cem Vakfı 3 Yaşında” [Cem foundation is 3 years old], Cem Dergisi 3, no. 80 (1998): 1. 
While stressing the important impact of Islam on Alevism, Cem Vakfl does not reject the fact that Turkic and Anatolian elements and beliefs are also present in it. This does not prevent them from endorsing an Alevi-Islamic Synthesis. In fact, Hıdır Akbayır, secretary-general of the Foundation as well as a dede, narrated one of the Shamanistic rituals of his mother:

When the new moon rises in the sky, my mom, may she rest in peace, used to go outside at night and say her prayers and recite her Islamic creed Shahada. There is no such thing in Islam, but we are all affected by such things. Anatolia is a cultural mosaic where all the beliefs blended together. ${ }^{49}$

Erdoğan Döner, who was the current head of Cem Vakfl in 2019, argued that Alevism was born with Ali, and the ones who supported and believed his philosophy called themselves "Alevi." He also added:

Alevism is the essence of Islam; it is Islam itself. Alevis define themselves in this way and claim that they are the descendants of Ahl al-Bayt. Alevis accept that Alevism is not another interpretation of Islam, but it is the essence of it. ${ }^{50}$

Akbayır stressed their belief that Alevism is a different interpretation of Islam and added:

Alevis have faith in the Prophet, and they believe Muhammad is the last prophet and his book is Quran. But we believe that there is a difference between Ahl al-Bayt interpretation of Quran and other interpretations .... There are some verses related to Ali and Ahl al-Bayt, and we believe in the Ahl-al Bayt interpretation. During the last Hajj of Muhammad in 632, he appointed Ali as his successor. One of the important hadiths states the saying of Muhammad is that "If I am the city of knowledge, Ali is its gate." Again, in Al-Surah 42 Ayah 23 he demands love for Ahl alBayt. When all of these come together, Alevis created a belief different than Sunni Islam. They blended the love of Ahl al-Bayt with love of human beings. Because the Creator blew its spirit into human beings and all his creations. Human beings are sacred for us, because God created them, but if the human beings did not exist, there would not be any God, either. And this lies at the heart of Alevi-Islamic belief. ${ }^{51}$

Here, Akbayir stressed that Ali was the rightful Caliph after $\mathrm{Mu}-$ hammad and repeated verses from Quran to prove his statements. In a way, he clearly attempted to manifest that Quran is

49. Hıdır Akbayır, "Interview," interview by Pınar Akdeniz, May 2, 2019.

50. Erdoğan Döner, "Interview," interview by Pınar Akdeniz, May 2, 2019.

51. Akbayır, interview. 
open to interpretation in certain aspects, even though Alevis accept it as a holy book. Hence, Alevism combines these values (i.e., Prophet Muhammad, Quran, interpretations of meanings from those who acquired knowledge and can interpret them) as well as the love for human being and melts them in a pot. But what matters the most, according to Akbayır, is to distinguish between what is apparent (zahir) and what lies beyond (batın). To give an example, Akbayır used the example of sugar and its colour. He stressed that when one asks the color of sugar to an ignorant person, they would say that it is white. But when one heats the sugar, it caramelizes and changes color. So, the question is, he asked, is it white or brown? This is what differentiates the apparent from the invisible. This is why Alevis focus on batın rather than zahir.

It is important to stress that Cem Vakfi established an organization under the name "Directorate of Alevi Islam Religious Services" (Alevi Islam Din Hizmetleri Başkanlığı (AIDHB)) in 2001, which aimed to promote the Alevi-Islamic faith as well as bringing dedes and babas together from every province of Turkey. The directorate's name mirrors the state-run Directorate of Religious Affairs (Diyanet Işsleri Başkanlığı), but the words Alevi and religion were specifically added to attenuate this resemblance. The word religion (din) was then removed from the organization's name in 2016, in order to avoid tensions with Turkish state authorities. Seyit Karababa, a dede and member of the AIDHB, defined Alevis as follows:

A society that lives its faith based on a unique set of rules but also connects its faith to Islam. It is a society that never accepted they are outside of Islam, but they were always forced to be left outside. We always say that we are the essence of Islam, Quran is our Quran and the Prophet is our Prophet. Sometimes our Sunni friends ask whether we are inside or outside Islam. But what we believe is we believe in God, the Quran, the Prophet, Ali, and the Twelve Imams. ${ }^{52}$

He then added that even though he did not want to compare it with the Diyanet that represents Sunnis, AIDHB is an important institution, because it represents the Alevi faith. Karababa stated that the AIDHB works only on the faith level of Alevism, so that no one can intervene:

When there is a need for a dede, we send them from here. We handle all funeral arrangements and rituals accordingly. That is why AIDHB handles the faith dimension of Alevism. We send dedes and zakirs and arrange funerals and regardless of whoever asked for help. ${ }^{53}$

52. Seyit Gazi Karababa, “Interview,” interview by Pınar Akdeniz, May 3, 2019. 53. Ibid. 
According to Döner, the AIDHB is an important institution not only for providing services to Alevis but for also educating dedes: More than fifteen thousand dedes coming from both Turkey and abroad have received education about how to conduct cem and become ritual leaders. All dedes are certified, and their lineages (i.e. ocaks) are recorded. ${ }^{54}$

Since Cem Vakfi has its own cemevi and dedes, it is also interesting to observe that while other Alevi faith-based organizations hold their cems without any segregated areas allocated for men and women, in Cem Vakfi's cem men and women sit separately and use different doors to enter the cemevi. While women sit on the right, men sit on the left. Furthermore, during cem, they all prostrate themselves, their foreheads touch the ground as in namaz and they recite Surah Nur in Turkish that they all know by heart. This idiosyncratic cem could be due to Cem Vakfi's perspective on Alevi-Islamic Synthesis.

The other organization that considers Alevism within and as the essence of Islam is the World Ahl al-Bayt Foundation (Dünya Ehl-i Beyt Vakfi (DEBV)), founded on April 29, 1997 by Fermani Altun. The perspective of the Foundation about Alevism has been conveyed by Altun on various occasions. In his view:

Alevism is a Sufi interpretation of Islam. In fact, it is the essence of Islam. Islam that is not following the way of Ahl al-Bayt is invalid, because our Prophet said: 'whoever loves me also loves my Ahl al-Bayt. Their enemy is my enemy and my enemy are their enemy.' He also said that "Ali and I were made from the same light" and "If I am the city of knowledge, Ali is its gate." ... Faiths such as Shiite, Kızılbaș, Alevi and Bektashi are all essence of Islam. ${ }^{55}$

Altun defined Alevism as an interpretation of Islamic mysticism (tasavvuf). He put emphasis on the Prophet's family, Ahl al-Bayt, which also lent its name to the organization. In fact, to make a stronger point, Altun equated Sunni Islam with Alevism. In his definition of Sunni Islam, Altun immediately traced similarities with Alevism and stated them clearly:

Sunni Islam means to be attached to the Sunnah of our Prophet. But our Prophet also once said that the ones who carry out my Sunna in the right way is my Ahl al-Bayt. Ahl al-Bayt originated from the Prophet. Hence, every Alevi is Sunni and every Sunni is Alevi because their descendants are the same. ${ }^{56}$

54. Döner, interview.

55. Fermani Altun, “Interview," interview by Pınar Akdeniz, May 6, 2019.

56. Ibid. 
In the English section of the Foundation's website it was declared:

In the torch of the World Ahl al-Bayt Foundation there is no separation, there is unity, love, affection, there is no Alawi[sic]-Sunni, there is Islamic brotherhood, there is human brotherhood; Because our Lord almighty who has created the universe has given all people the same values and the same right way .... Learning these values in the correct manner is the greatest service and the greatest charity. Those who divide the Islam with their cults and bigotry, those that ideologize it, render it hostile with their terrors, reigns, cruelty and separations are those that cause the greatest damage to the Islam and the humanity. ${ }^{57}$

In Altun's view, since Ali and his descendants as well as Muhammad's kin come from his closest circle and they are the Ahl alBayt, and since they all follow the Prophet's Sunna, there is no difference between Alevism and Sunni Islam. Therefore, equated them. Not only did the DEBV expand the boundaries of Alevism, claiming that both Alevism and Islam share so many points, but it also engaged in equalization, one of the varieties of transvaluation, where Alevism is understood as a faith that is virtually identical with Islam.

\section{Conclusion}

The findings of this study manifest that Alevi organizations do not have a single definition of Alevism. Definitions presented show that the Alevism maintains an equivocal character. Following Bilici's categorization, groups viewing Alevism as a secular ideology or heterodox mysticism are likely to consider it as a universal faith. Groups viewing Alevism as a branch of the Ja'fari school of Islamic jurisprudence (figh) or Shiite Islam are likely to consider Alevism as a denomination of Islam. In most cases, however, it is observed that there is a tendency to define Alevism in relation to Islam, irrespectively of whether this has positive or negative connotations. This shows that there are clear boundaries and boundary contestations among Alevis themselves. On the one hand, the group of Alevi organizations defining Alevism as a belief that has been affected by many religions and rituals contracts the boundaries of Alevism vis-à-vis Sunni Islam. On the other hand, by stating that Alevism has long predated Islam and encountered it, as it was evolving to its present form, they tend to expand the boundaries of their belief by stressing its

57. Ahl al-Bayt Foundation, "About the Foundation," 2018, https://www.ehlibeyt.org.tr/?about-foundation-61/about-foundation-97.html. 
universalism. They stress that it is an all-encompassing belief with moral values that could be applicable and valid for all humanity. Other Alevi organizations, which argue that Alevism has close ties with Islam, especially its Sufi version, and perceive Alevism as the essence of Islam, tend to expand the boundaries of Alevism and connect it with a wider understanding of Islam. In doing so, Alevi elites in the name of preserving Alevism and keeping it alive end up deepening cleavages among Alevis in Turkey by engaging in internal boundary contestations. Situating Alevism vis-à-vis Sunni Islam also serves as a guide to Turkey's domestic political dynamics and the different visions of Alevi organizations regarding Alevism within Turkish society. The willingness of Alevi organizations to collaborate with the AKP government whenever the latter decided to engage the Alevi community has been strongly correlated with their attitude toward Sunni Islam. Nevertheless, the attitude of the Sunni majority toward Alevism and its representatives does not appear to be affected by such nuances. Sunni views of the Alevis remained pegged to Turkey's vacillations around the liberal democratic model and the often tactical moves of the AKP administration on the domestic and international levels. This conclusion holds beyond the Alevi case, in all ethnic or religious minorities whose boundaries remain debated, either through in-group contestations or through varying attitudes of the majority communities. 